\title{
Effects of terms and norms of biostimulator application on local peanut yield and seed quality
}

\author{
Jonibek Khudaykulov ${ }^{1,}$, , Sarvinoz Togaeva ${ }^{1}$, Chulpanoy Kashkabaeva ${ }^{1}$, Zayniddin \\ Abirov ${ }^{1}$, and Shukhrat Shodmonov ${ }^{1}$ \\ ${ }^{1}$ Tashkent State Agrarian University, 100140, Universitetskaya str., 2 Tashkent, Uzbekistan
}

\begin{abstract}
In this article, the analysis of the field experiments conducted in the Tashkent province, which was aimed at improving the technology of high-quality production, and economic efficiency of peanuts in the conditions of the typical gray soil and climate, was given. In the field experiments, the effect of Microzym-2 biostimulator on growth, development, yield elements, yield and seed quality of local peanut varieties "Salomat" (standard) and "Mumtoz" was studied. Accordingly, before sowing of peanut seeds, the biostimulator Microzym-2 was applied at a rate of $30 \mathrm{l} / \mathrm{t}$, as result the yield of legumes was $1.4 \mathrm{t} / \mathrm{ha}$ higher in "Salomat" (standard) and 1.1 t/ha higher in the class "Mumtoz" than in the control variant $(11.7 \mathrm{t} / \mathrm{ha})$. When peanut varieties were supplemented with mineral fertilizers $\mathrm{N}_{150} \mathrm{P}_{150} \mathrm{~K}_{100} \mathrm{~kg} / \mathrm{ha}$, and treated with Microzym-2 biostimulator before the sowing and during the flowering periods, 29.3 q/ha of "Salomat" variety and 33.2 q/ha of "Mumtoz" harvest were obtained. It was found that Microzym-2 biostimulator in sowing peanuts was cost-effective.
\end{abstract}

\section{Introduction}

Today improving the yield of oilseeds, including peanuts, and seed quality is vitally important towards meeting the food needs of the world population. Worldwide, peanuts are grown in 117 countries and cover an area of 27.66 million hectares, with a gross yield of 43.98 million tons and an average yield of 1.59 tons per hectare [1]. Peanuts cover 56 percent of the Asian continent, 40 percent of Africa's arable land, and account for 68 percent or 25 percent of total output. Today, the scientific substantiation of the technology of producing peanut varieties and the increase of gross yield in the provision of the population with nutritious food products is one of the urgent issues [1, 2]. Scientific research on ecological testing and selection of high-quality varieties of peanuts in different soil and climatic conditions, improving yields and seed quality, as well as technology of cultivation are conducted by leading international research centers and higher education

\footnotetext{
${ }^{*}$ Corresponding author: jonibek.khudaykulov@yandex.uz
} 
institutions, including the American Peanut Research and Education Society, UFUniversity of Florida IFAS Research (USA), International Crops Research Institute for the Semi-Arid Tropics (ICRISAT), International Center for Agricultural Research in the Dry Areas (ICARDA), Shandong Peanut Research Institute (China), KOPIA (South Korea), Krasnodar State Agrarian University (Russia), Research Institute of Botany and Tashkent State Agrarian University (Uzbekistan) [1,3].

Scientific researches on improvement of agrotechnology of peanut growing in the world have yielded the following results: including cultivation of new, high-yielding and highquality varieties, reduction of costs in peanut processing, production and export of competitive, environmentally friendly products in accordance with consumer demand and supply (American Peanut Research and Education Society, UF-University of Florida (IFAS Research), increasing the yield and protein and oil content of peanut varieties [3]. Specifically, high and sustainable yields, taking into account the biological and genetic characteristics of the variety, planting time, rate, mineral fertilizers nutrition, water demand and dependence on applied agro-technical measures (ICRISAT, ICARDA) were identified $[3,5]$. As a result of scientific research on selection, biotechnology, physiology, disease, pest and weed protection of nut crops, nutritious and high-quality products were delivered to the food industry and livestock (Shandong Peanut Research Institute). Furthermore, different methods of planting peanuts, such as under film, drip irrigation, application of growth regulators and resource-saving technologies have been developed (KOPIA, Krasnodar State Agrarian University) [4, 6].

Today, the following priority areas of research are being conducted in the production of peanuts in countries around the world: including the creation of new and promising varieties of peanuts adapted to the soil and climatic conditions of each region; increase the consumption of legumes, improve the supply of valuable raw materials for the pharmaceutical industry and confectionery, the development of agro-technologies that ensure sustainable production [4]. The countries with the largest walnut cultivation in the world are the United States, China, India, Argentina, Brazil, South Africa, Russia, Italy, Spain, Australia, and the Caucasus. In these countries, scientific research has been conducted on ecological testing of new varieties of walnuts, selection and proper placement of varieties suitable for soil and climatic conditions of each region, cultivation of high and quality crops, storage, processing and export $[3,6]$.

However, insufficient research has been conducted on the selection of varieties suitable for growing peanuts as a main crop and as a secondary crop after winter wheat and their optimal planting times, irrigation regimes, demand for mineral fertilizers and the use of growth-regulating biostimulators. Therefore, this study was aimed at scientifically researching selection of fast-ripening, high-yielding foreign peanut samples suitable for the conditions of typical gray soils of Tashkent province, optimal planting times of local varieties, feeding norms with mineral fertilizers, irrigation regime and biostimulator application technologies, morpho-biological properties of peanuts, photosynthetic activity. The main objectives of the study were 1) assessment of growth, development, maturity, productivity and quality of foreign walnut varieties and samples from the world gene pool, as well as the selection of varieties and samples suitable for the soil and climate of Tashkent province; 2) to study the effect of optimal sowing times of local walnut varieties as a primary and secondary crop on morpho-biological properties, photosynthetic activity, yield and oil content in seeds; 3 ) to determine the effect of optimal irrigation regimes and fertilization standards on nut growth, developmental phases, leaf level, yield and yield structure; 4) to study the effectiveness of the use of the biostimulator Microzym-2 in the 
cultivation of peanuts; 5) to determine the cost-effectiveness of planting technologies, irrigation and mineral fertilizers, as well as the use of biostimulators in the cultivation of peanut varieties as a primary and secondary crop $[4,5]$.

\section{Study area}

The scientific research was carried out at the Tashkent State Agrarian University Agricultural Research and Training Experimental Farm. The experimental farm was located in the upper stream of the Chirchik River, $481 \mathrm{~m}$ above sea level, $41^{\circ} 11^{\prime \prime}$ north latitude and $38^{\circ} 31^{\prime \prime}$ east distance in Kibray district of Tashkent province.

The climatic conditions of Tashkent province are continental and arid. However, the climatic conditions are specific, the air temperature decreases from the plains of the region to the mountainous areas, and the amount of atmospheric precipitation increases. In the plains and hills, the temperature of the winter months is unstable, fluctuating over the years. The coldest month in the region is January, with temperatures ranging from $0{ }^{0} \mathrm{C}$ to $29{ }^{\circ} \mathrm{C}$. The amount of atmospheric precipitation in the region also varies. In the plains, the annual precipitation is $261-316 \mathrm{~mm}$, in the foothills $366-435 \mathrm{~mm}$, and in the mountains $700-895 \mathrm{~mm}$. The sum of the useful seasonal temperatures required for the care of field crops in April-October averages $2200-2400{ }^{\circ} \mathrm{C}$ and the duration of non-cold days averages 235-240 days. The highest rainfall is in winter and spring, averaging 400-500 $\mathrm{mm}$. The average annual rainfall is $510-520 \mathrm{~mm}$, so it is recommended to irrigate field crops.

The soil of the experimental farm was a typical gray soil that has been irrigated since ancient times. The soil contains $0.8-1.0 \%$ humus, about $0.058-0.089 \%$ nitrogen, about $0.141-0.184 \%$ phosphorus and about $0.154-0.148 \%$ potassium. The soil was not saline. This soil differs in water permeability, the complexity of softening. Groundwater was located in a deep layer of 15-18 m. For irrigation, the experimental farm used water from the Gray Canal, which flows through the northern part.

Table 1. Preliminary agrochemical indicators of experimental field soils (2006)

\begin{tabular}{|c|c|c|c|c|c|c|}
\hline \multirow{2}{*}{$\begin{array}{c}\text { Soil depth } \\
\text { cm }\end{array}$} & \multicolumn{3}{|c|}{ General forms of nutrients, \% } & \multicolumn{3}{c|}{ General forms of nutrients, mg/kg } \\
\cline { 2 - 7 } & Humus & Nitrogen & phosphorus & $\mathrm{N}_{-} \mathrm{NO}_{3}$ & $\mathrm{P}_{2} \mathrm{O}_{5}$ & $\mathrm{~K}_{2} \mathrm{O}$ \\
\hline $0-30$ & 0.920 & 0.083 & 0.152 & 4.7 & 47.1 & 180.7 \\
\hline $30-50$ & 0.715 & 0.065 & 0.134 & 3.1 & 40.3 & 140.0 \\
\hline
\end{tabular}

\section{Methods}

\subsection{Materials}

Weather data for the years of the experiments were obtained from the "Akkavak" agrometeorological station under the Research Institute of Cotton Breeding, Seed Production and Agrotechnology (PSUEAITI) in Kibray district of Tashkent province. The varieties of local peanuts, such as "Tashkent-112", "Qibray-4", "Salomat" and "Mumtoz", planting dates, irrigation regimes, nitrogen, phosphorus and potassium fertilizers and a biostimulator Microzym-2 were studied in this research. 


\subsubsection{Description of domestic and foreign walnut varieties}

Description of the "Mumtoz" variety. The L-5 X ICGV-94088 (India) collection was created by mass selection. The main authors are M.E.Amanova, A.S.Rustamov, Sh.Nigam, R.F.Mavlyanova, Z.I.Kholiqulov [6]. It belongs to Virginia, and the plant is semi-erect, moderately branched. The shape of the large dukka is fat, wavy, the surface is slightly deep, pale yellow, the skin is medium-rough, the middle is slightly narrow, the seam is medium. The color of the seeds is dark red, oblong-oval in shape. The variety is mediumripe, ripening in 138-145 days. Yields average 27-28 q/ha. Weight of 1000 seeds is 686.0710.0 gr. Suitable for assembly with mechanism. Legume has a high adhesion of 5.0 points, maturity of $80.0 \%$. The fat content of the grain is $48.5 \%$, the protein is $18.0 \%$. The variety is resistant to agricultural diseases and insects. Entered into the State Register in 2006 [69].

Description of the "Salomat" variety. Uz008418 was created by mass selection from the collection sample, and the main authors are M.E. Amanova, A.S. Rustamov, Sh. Nigam, and Z.I. Kholiqulov [7, 8]. It belongs to the Valencia variety type, the plant grows upright, the stem is of medium height, the pods are large. The shape of the pod is wavy, slightly deep, pale yellow, the skin is medium-rough, the nut is 3 to 4 seeds, the middle is slightly constricted, the stitch is medium, the color of the seed is dark red, oblong-oval. The variety is medium-ripe, ripening in 138-140 days. The weight of 1000 seeds are $540.0 \mathrm{~g}$. The variety is large-fruited, large-grained and productive. Suitable for assembly with mechanism. Legume has a high adhesion of 5.0 points, ripeness of $85.0 \%$. The fat content of the grain is $50.0 \%$, protein is $17.0 \%$.

Composition and properties of micro-stimulant biostimulator. The biostimulator "Mikrozim-2" was developed by scientists of the Institute of Microbiology of the Academy of Sciences of Uzbekistan. This drug affects the growth and development of plants, increases productivity, disease and pest resistance. In 2008-2010, the biostimulator "Mikrozim-2" passed the state test. In 2011, the country was included in the list of pesticides and agrochemicals applied to plants in agriculture, has a toxicological, environmental certificate, drug preparation program and production protocol. The biostimulator "Mikrozim-2" contains enzymes, phytohormones, antibiotics. Biostimulator "Mikrozim-2" has the following features, such as growth and development of plants, accelerates endogenous factors in seed development, improves metabolism by accelerating physiological and biochemical processes in plants, increases disease resistance, reduces root rot, has an effective effect on seed germination when treated with the drug, increases the acceleration of organic matter in the soil, environmentally friendly, and does not harm plants and the environment. The results of tests on legumes in Andijan, Fergana, Namangan, Surkhandarya and Tashkent provinces of the country that the biostimulator "Mikrozim-2" was sufficiently effective to increase productivity.

\subsubsection{Field and laboratory experiments}

In conducting field and laboratory experiments, phenological observations, biometric measurements and yield determination, the methodological manuals "Methods of State Variety of Agricultural Cultivation", "Methods of Field Experiments", "Scientific Research in Botany" were used. Agrophysical and agrochemical analysis of soils was carried out on the basis of "Methods of agrochemical, agrophysical and microbiological research in pollinated cotton fields". The data obtained in the field experiments were analyzed mathematically statistically using Microsoft Excel program based on the method of B.A. Dospekhov [10, 11]. 
Field experiments were conducted in the conditions of typical gray soils of the Tashkent State Agrarian University agricultural research and educational experimental farm (20142016). The field experiments are annually tested and evaluated by a special commission of the Uzbek State Agrarian University and the Tashkent State Agrarian University. Ammonium nitrate from nitrogen fertilizers (NH4NO3-33-34\% nitrogen), amorphous from phosphorus fertilizers (NH4H2PO4-11-12\% nitrogen, 46-60\% phosphorus), potassium chloride from potassium fertilizers ( $\mathrm{KCl}-57 \%$ potassium) were used to feed peanuts. Nitrogen in amorphous was taken into account in determining the annual norms of mineral fertilizers.

\subsubsection{Phenological observations}

The following phenological observations, calculations, laboratory analyzes were carried out on the peanut crop in the experiment. In the peanut plant, the germination power of seeds under laboratory conditions was determined at a constant temperature of $+25^{\circ} \mathrm{C}$ for 10 days, germination at 6 days. Seed germination rate was observed in all variants of experimental repetitions, and the number of sprouted grasses was determined at 3 points of all options in seedling thickness $3.5 \mathrm{~m}^{2}$ (length $5 \mathrm{~m} \mathrm{x}$ width $0.7 \mathrm{~m}=3.5 \mathrm{~m}^{2}$ ). Phenological observations (periods of germination, branching, flowering, nut formation and ripening) were carried out in calculated plants, and seedling thickness of nut varieties was determined at 3 points in all variants and returns. Furthermore, peanut varieties were determined by leaf level by the method of A.A. Nichiporovich, and in each variant, the following was determined in 30 calculated plants: stem height was determined during the periods of branching, flowering, nut formation and ripening of nuts; the number of fully ripened, unripe nuts in a bush (pieces) and their ratio (\%) were determined; the number of seeds formed in the pods of a single plant; seed weight per bush and weight of 1000 seeds; in each iteration, the weight of the stem from the counted plants (10 bushes) was determined (as fodder for livestock) [12,13]. During the harvest period, the plants were excavated from 3 points of repetition of all experimental options, in which the peanuts were separated and the yield of nuts and hay $(\mathrm{q} / \mathrm{ha}$ ) was calculated by weighing on an electronic scale [12$14]$.

\subsection{Soil experiment}

Agrochemical analysis of the soil was carried out during the experiment. In order to determine the agrochemical composition of the soil, before starting field experiments and harvesting, samples were taken from the topsoil $(0-30 \mathrm{~cm})$ and subsoil $(30-50 \mathrm{~cm})$ layers of soil, especially a) total humus content (by I.V. Tyurin method); b) total amounts of nitrogen and phosphorus in the soil (in the methods of I.M. Maltseva L.N. Gritsenko); c) nitrate nitrogen by calorimeter method; mobile phosphorus was determined by B.P. Machigin, exchangeable potassium by P.V. Protasov methods on a flame photopolarimeter. Furthermore, agrophysical studies were carried out, and accordingly, the volume weight of the soil in the layer $0-50 \mathrm{~cm}$ was determined by the method of NA Kachinsky at the beginning and end of the application period [6,8], and soil moisture capacity was determined at the beginning of the nut application period. The limited field moisture capacity was determined from soil samples before each irrigation, and irrigation standards for peanuts were measured using a $0.5 \mathrm{~m}$ wide Cipolletti water meter [7]. 
Quality indicators of seeds were determined in the laboratory, and peanut yield was analyzed mathematically and statistically using the method of multivariate analysis of variance analysis in the manual "Methods of field experiment" by BA Dospekhov and the computer program Microsoft Excel. Based on the experimental system, the technology of using a growth-regulating biostimulator "Microzym-2" was studied. In the experiment, scientific research was conducted to determine the effectiveness of the application of the biostimulator "Microzym-2" before sowing, during the flowering and budding phases, as well as in the application of mineral fertilizers $\mathrm{N}_{150} \mathrm{P}_{150} \mathrm{~K}_{100} \mathrm{~kg} / \mathrm{ha}$ [6-8].

Table 2. Development of technology for the use of the biostimulator Microzym-2 in the cultivation of nuts (2014-2016).

\begin{tabular}{|c|c|c|c|c|}
\hline \multirow[b]{2}{*}{ № } & \multirow[b]{2}{*}{ Experiment options } & \multicolumn{3}{|c|}{ Terms of use } \\
\hline & & Before sowing & $\begin{array}{c}\text { During } \\
\text { flowering and } \\
\text { legume } \\
\text { periods }\end{array}$ & $\begin{array}{c}\text { Mineral } \\
\text { fertilizer } \\
\text { standards, } \\
\text { kg/ha }\end{array}$ \\
\hline & \multicolumn{4}{|c|}{ "Salomat" variety } \\
\hline 1 & Control (without fertilizers) & - & - & - \\
\hline 2 & Control (with fertilizers) & - & - & $\mathrm{N}_{150} \mathrm{P}_{150} \mathrm{~K}_{100}$ \\
\hline 3 & Microzym-2 biostimulator & $301 / t$ & & \\
\hline 4 & Microzym-2 biostimulator & $301 / \mathrm{t}$ & 40 1/ha & \\
\hline 5 & $\begin{array}{l}\text { Microzym-2 biostimulator and } \\
\text { mineral fertilizer }\end{array}$ & $301 / \mathrm{t}$ & - & $\mathrm{N}_{150} \mathrm{P}_{150} \mathrm{~K}_{100}$ \\
\hline 6 & $\begin{array}{l}\text { Microzym-2 biostimulator and } \\
\text { mineral fertilizer }\end{array}$ & $301 / \mathrm{t}$ & $40 \mathrm{l} / \mathrm{ha}$ & $\mathrm{N}_{150} \mathrm{P}_{150} \mathrm{~K}_{100}$ \\
\hline \multicolumn{5}{|c|}{ "Mumtoz" variety } \\
\hline 7 & Control (without fertilizers) & - & - & - \\
\hline 8 & Control (with fertilizers) & - & - & $\mathrm{N}_{150} \mathrm{P}_{150} \mathrm{~K}_{100}$ \\
\hline 9 & Microzym-2 biostimulator & $301 / \mathrm{t}$ & & \\
\hline 10 & Microzym-2 biostimulator & $301 / \mathrm{t}$ & 40 1/ha & \\
\hline 11 & $\begin{array}{l}\text { Microzym-2 biostimulator and } \\
\text { mineral fertilizer }\end{array}$ & $301 / \mathrm{t}$ & - & $\mathrm{N}_{150} \mathrm{P}_{150} \mathrm{~K}_{100}$ \\
\hline 12 & $\begin{array}{l}\text { Microzym-2 biostimulator and } \\
\text { mineral fertilizer }\end{array}$ & $301 / \mathrm{t}$ & $40 \mathrm{l} / \mathrm{ha}$ & $\mathrm{N}_{150} \mathrm{P}_{150} \mathrm{~K}_{100}$ \\
\hline
\end{tabular}

\subsection{Agronomic measures in the study}

Peanuts were stored in a dry, cool place until the peanut seeds were planted. During the years of the experiment, the seeds were carefully crushed by hand. Preparation of the soil for planting began with the removal of the remains of past plants. Collected weed debris was removed from the field. Before the autumn plowing, $100 \%$ of the annual norm of phosphorus and potassium fertilizers was applied per hectare, and peanut planting areas were plowed to a depth of 30-35 cm using LD-100 (PD-4-45) two-tiered plows attached to a Magnum (ARION 850) tractor. The edges of the crop field were cleared of weeds and the rectangular furrows were completely plowed. Mineral fertilizers were applied on PMU-0.5, 
RTO-4 and ROU-6 units used with TTZ-80.10 tractor. In the spring, when the soil subsided, preparations were made for planting. There was a chisel and a storm. For seed, healthy and large peanuts were selected each year and prepared by peeling 20-30 days before planting using manual labor. Peanuts were planted at an average depth of 4-6 cm when soil temperature was above $15-17^{\circ} \mathrm{C}$. Since the field experiments were carried out in small areas, the seeds were sown in a 70x10x1 scheme using manual labor on a ridge with a row spacing of $70 \mathrm{~cm}$. The experimental results showed that the use of machinery for planting walnuts in large open areas and between rows of young gardens is cost-effective. When sowing peanut seeds with the help of machinery, special attention was paid to the high-quality preparation of the soil. is because if the soil is uneven, the seeds will not fall evenly and the seeds will not be well buried in the soil $[10,11]$.

Irrigation timing was determined in the most accurate and correct way, i.e., by determining the soil moisture relative to the limited field moisture capacity (LFMC). Irrigated 4-5 times during the season at a rate of $600-700 \mathrm{~m}^{3} / \mathrm{ha}$. Irrigation regime was ensured to be $70-70-65 \%$ of the soil relative to the limited field moisture capacity. Emphasis was placed on the importance of loosening crop row spacing, avoiding excess moisture, raising soil temperature, improving air circulation, and weed control for the good development of the nut crop. The first cultivation and mowing were carried out after the grasses were fully germinated. The first food was given and watered. The second cultivation was treated between rows, leaving a protection zone of $6-8 \mathrm{~cm}$, the third cultivation $8-10 \mathrm{~cm}$, and the last $10-12 \mathrm{~cm}$. In field experiments, blades, KKO and or naralnik were added to prevent damage to the plant during cultivation and to bury it in the soil. The second feeding was carried out after the plant has entered full bloom. Seedlings were watered 5-6 weeks after flowering. Humming was done 2 times during the entire growth period.

Proper timing of harvest is of great importance and contributes to product quality when harvested ahead of schedule. For this reason, peanuts were harvested on hot and dry days, in short periods of time. Due to the small size of the experimental area in this research work, the ripened crop was harvested using consecutive manual labor at specified intervals. After the initial counted plants were harvested, the remaining crop was massively harvested When the ripe crop was harvested from the second decade of September to early October (on rain-free open days), it was kept in the open field for several days without being separated from the stem. During this period, the moisture content of the seeds decreased, and the gynophores dried up, and the nuts were easily separated from the plant root. After the nuts were separated from the stalks, the remaining stalks were pressed using a CASEIII unit attached to a modern MX-80 tractor $[4,5]$. In the late harvest, the moisture content of nuts was $40-60 \%$, and in the wind-swept buildings were spread and dried to a thickness of 5-6 cm. The seeds were sorted after drying (humidity 14-15\%). For next year planting or long-term storage, well-dried, dark-seeded, unpeeled, mechanically undamaged, typical of the variety, large nuts were isolated.

\section{Results and Discussion}

\subsection{Climate condition}

Data on weather temperatures and precipitation for 2014-2016 show that the average monthly air temperature observed in January was $2.6{ }^{\circ} \mathrm{C}$ in $2014,2.4{ }^{\circ} \mathrm{C}$ in 2015 , and 6.1 
${ }^{\circ} \mathrm{C}$ in 2016 , which is much higher. The warm air temperature was higher by $0.2{ }^{\circ} \mathrm{C}$ than the annual average monthly air temperature. According to the analysis of precipitation, the precipitation in January was $33.2 \mathrm{~mm}$ in 2014, followed by $39.0 \mathrm{~mm}$ in 2015 and $36.3 \mathrm{~mm}$ in 2016. Table 3 depicted that the average monthly air temperature in the first March of the spring season was 8.9-7.6-12.9 ${ }^{\circ} \mathrm{C}$, which was $4.9{ }^{\circ} \mathrm{C}$ higher in 2016 than the multi-year average air temperature. The amount of precipitation in March was 100.4-91.4-115.4 mm, respectively. These figures indicate that there was relatively more precipitation compared to the amount of perennial precipitation $(85.7 \mathrm{~mm})$. During the years of the experiment, the average monthly air temperature in May was $23.1^{\circ} \mathrm{C}, 22.1^{\circ} \mathrm{C}, 20.7^{\circ} \mathrm{C}$, correspondingly, which was higher by $3.0^{\circ} \mathrm{C}, 2.0^{\circ} \mathrm{C}, 0.6^{\circ} \mathrm{C}$ than the average monthly air temperature for the period. Furthermore, the average annual rainfall was $40.3 \mathrm{~mm}$ in May, compared to 15.2 ${ }^{\circ} \mathrm{C}, 85.5{ }^{\circ} \mathrm{C}$ and ${ }^{\circ} \mathrm{C} 54.6 \mathrm{~mm}$ during 2014-2016. According to the data obtained, in 2014 it was $25.1 \mathrm{~mm}$ less, in 2015 and 2016 it was 45.2 and $14.3 \mathrm{~mm}$ more than the average precipitation. Precipitation for the period were $11.6 \mathrm{~mm}$ in June, $4.2 \mathrm{~mm}$ in July, and 2.6 $\mathrm{mm}$ in August, respectively. In the study period, especially by October, a decrease in the average monthly air temperature and, conversely, an increase in the amount of precipitation was observed. The average monthly air temperature during these years was $12.7^{\circ} \mathrm{C}, 14.4$ ${ }^{\circ} \mathrm{C}$ and $11.6{ }^{\circ} \mathrm{C}$, correspondingly and the amount of precipitation was $61.4 \mathrm{~mm}$ in 2014 , followed by $104.8 \mathrm{~mm}$ in 2015 and $38.2 \mathrm{~mm}$ in 2016. It is advisable to harvest ripe peanuts in a short period of time on days when the autumn weather temperature was hot, dry and the amount of precipitation is the lowest (Table 3).

Table 2. Average temperature and precipitation during 2014-2016

\begin{tabular}{|l|c|c|c|c|c|c|c|c|}
\hline & \multicolumn{3}{|c|}{ Average air temperature, ${ }^{\circ}$ C } & \multicolumn{4}{c|}{ Average precipitation, mm } \\
\cline { 2 - 9 } Months & $\begin{array}{c}\text { Average } \\
\text { temperat } \\
\text { ure for } \\
\text { the years }\end{array}$ & $\mathbf{2 0 1 4}$ & $\mathbf{2 0 1 5}$ & $\mathbf{2 0 1 6}$ & $\begin{array}{c}\text { Average } \\
\text { precipitatio } \\
\text { n for the } \\
\text { years }\end{array}$ & $\mathbf{2 0 1 4}$ & $\mathbf{2 0 1 5}$ & $\mathbf{2 0 1 6}$ \\
\hline January & 0.2 & 2.6 & 2.4 & 6.1 & 62.3 & 92.4 & 98.2 & 95.9 \\
\hline February & 2.4 & -3.4 & 5.9 & 7.7 & 74.5 & 38.7 & 103.6 & 7.5 \\
\hline March & 8.0 & 8.9 & 7.6 & 12.9 & 87.8 & 100.4 & 91.4 & 115.4 \\
\hline April & 14.8 & 13.7 & 17.1 & 15.3 & 71.8 & 70.4 & 65.5 & 31.5 \\
\hline May & 20.1 & 23.1 & 22.1 & 20.7 & 39.9 & 15.2 & 85.5 & 54.6 \\
\hline June & 25.4 & 26.8 & 27.6 & 26.5 & 12.1 & 7.0 & 24.9 & 14.9 \\
\hline July & 27.2 & 26.3 & 29.1 & 27.9 & 4.0 & 0 & 0 & 1.6 \\
\hline August & 25.4 & 26.6 & 26.4 & 27.3 & 2.5 & 0 & 3.6 & 0 \\
\hline $\begin{array}{l}\text { Septembe } \\
\text { r }\end{array}$ & 20.0 & 20.7 & 20.1 & 23.8 & 4.8 & 1.0 & 4.8 & 5.8 \\
\hline October & 13.7 & 12.7 & 14.4 & 11.6 & 33.4 & 61.4 & 104.8 & 38.2 \\
\hline November & 7.4 & 5.2 & 7.4 & 5.7 & 55.2 & 76.4 & 98.3 & 57.3 \\
\hline December & 2.5 & 3.1 & 7.0 & 5.0 & 70.2 & 35.4 & 65.8 & 88.6 \\
\hline
\end{tabular}




\begin{tabular}{|l|l|l|l|l|l|l|l|l|}
\hline Average & 13.9 & 13.9 & 15.6 & 15.9 & 518.5 & 498.3 & 746.4 & 511.3 \\
\hline
\end{tabular}

\subsection{Effects of Microzym-2 on peanut varieties, "Salomat" and "Mumtoz"}

It was observed that the use of the stimulator Microzym-2 affected the growth and development of peanut varieties. In the experiment, the peanut varieties, "Salomat" and "Mumtoz" were planted, and phenological observations were made during their growth and development season. Accordingly, phenological observations showed significant differences in the biological properties of varieties and periods of action under the influence of external factors. After sowing the seeds of walnut varieties, the germination of seeds in field conditions was determined by counting the number of seedlings germinated in the calculated area (in $\mathrm{m}^{2} /$ piece). Depending on the germination status of more than $50 \%$ of the seeds, the germination periods of the seedlings of peanut varieties were recorded according to the variants. In this experiment, in addition to the factors studied for the germination period of peanut varieties planted in early spring, it was also observed that the effect of air temperature and the amount of natural precipitation was significant.

In experiments studying the effect of the biostimulator "Microzym-2" on the developmental stages of peanut varieties, local peanut varieties were planted in the last ten days of April. The germination of seeds for "Salomat" variety was on May 8 2014, May 1 2015 and May 6 2016, whereas for "Mumtoz" variety, it was May 9 2014, May 32015 and May 8 2016. The research results of the field germination showed that the seeds of varieties "Salomat" and "Mumtoz" in variants 1-7, that is, in the absence of fertilizers and biostimulators, sprouted seedlings on average were 11-13 days. In the experiment, it was observed that when seeds of peanut varieties were sown before sowing with the biostimulator Microzym-2, the seeds germinated 2-3 days earlier. The influence of the studied factors on the transition periods of peanut varieties to the flowering period was observed. In peanut varieties, the transition periods to flowering periods were determined according to the variants, depending on the state of transition of seedlings to flowering at more than 50\%. The flowering period in the variety "Salomat" in 2014-2016 was June 6, May 29 and June 2, respectively, and in the variety "Mumtoz" it was June 13, June 8 and June 13. According to the average data, in the 1st control variant of "Salomat" variety, that is, in the absence of fertilizers and biostimulator, the flowering period was on average 2830 days, and in the 7th control variant of "Mumtoz" variety, it was 34-36 days.

In the experiment, seeds of peanut varieties were treated with Microzym-2 biostimulator before sowing. In in 3-4 variants without the use of mineral fertilizers during the period, the flowering period for "Salomat" was June 5, May 29 and June 2, and for "Mumtoz" variety, it was June 12, June 7 and June 12. According to the analysis of 3-years flowering period, in these variants the average flowering period was 29-37 days, and by this time the "Salomat" variety showed early maturity compared to the "Classic" variety. It was observed that the transition of the peanut "Salomat" variety from flowering to the budding period was occurred on average 8-11 days, and in the "Mumtoz" variety, it took average of 12-15 days. By the time of ripening, late ripening features were considered in "Mumtoz" variety than in "Salomat" variety. Overall, the mineral fertilizers postponed the transition period in both varieties, by average 6-7 days than the control options. In 2016, it was observed that the effect of biostimulator application time and fertilization norms on the ripening period of peanut varieties was significant. In the control variant, the ripening period was 2-3 
September in the "Salomat" variety, and 12-15 days later in the Mumtoz variety, that is, 1517 September.

According to the analysis of the ripening periods in control options 1 and 7, "Salomat" repined on average 80-83 days whereas it took 81-83 days for "Mumtoz". Although the days were hot, the air temperature was favorable for plant growth, the completion of the vegetation period was determined by external morphological features, and harvesting began.

Table 3. Influence of Microzym-2 biostimulator on the developmental period of peanut variety

\begin{tabular}{|c|c|c|c|c|c|c|c|c|c|}
\hline \multirow{3}{*}{ № } & \multirow[b]{2}{*}{$\begin{array}{l}\text { Experimental } \\
\text { variants }\end{array}$} & \multicolumn{3}{|c|}{ Terms of use } & \multirow[b]{2}{*}{ 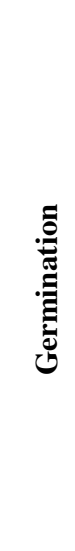 } & \multirow[b]{2}{*}{ 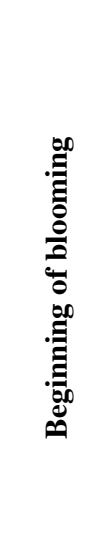 } & \multirow[b]{2}{*}{ 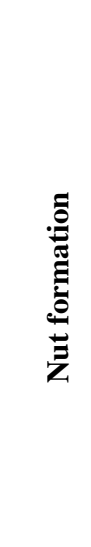 } & \multirow[b]{2}{*}{ 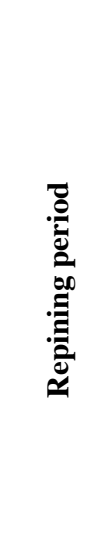 } & \multirow[b]{2}{*}{ 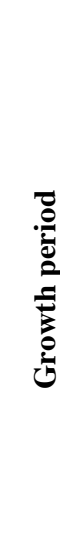 } \\
\hline & & 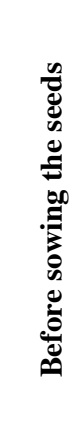 & 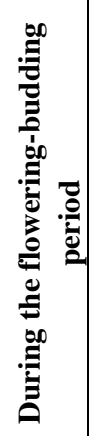 & 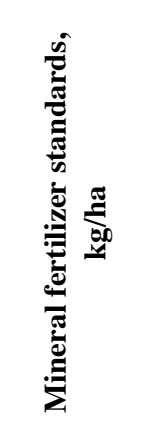 & & & & & \\
\hline & \multicolumn{9}{|c|}{ "Salomat" variety } \\
\hline 1 & Control & - & - & - & 6.05 & 2.06 & 11.06 & 2.09 & 119 \\
\hline 2 & Control & - & - & $\begin{array}{c}\mathrm{N}_{150} \mathrm{P}_{150} \mathrm{~K}_{10} \\
0\end{array}$ & 6.05 & 6.06 & 18.06 & 8.09 & 130 \\
\hline 3 & "Microzym-2" & $301 / \mathrm{t}$ & - & - & 4.05 & 2.06 & 12.06 & 5.09 & 124 \\
\hline 4 & "Microzym-2" & $301 / \mathrm{t}$ & $\begin{array}{c}40 \\
1 / \mathrm{ha}\end{array}$ & - & 4.05 & 4.06 & 15.06 & 10.09 & 129 \\
\hline 5 & $\begin{array}{c}\text { "Microzym-2" } \\
\text { +NPK }\end{array}$ & $301 / \mathrm{t}$ & - & $\begin{array}{c}\mathrm{N}_{150} \mathrm{P}_{150} \mathrm{~K}_{10} \\
0\end{array}$ & 4.05 & 6.06 & 19.06 & 15.09 & 134 \\
\hline 6 & $\begin{array}{c}\text { "Microzym-2" } \\
\text { +NPK }\end{array}$ & $301 / t$ & $\begin{array}{c}40 \\
1 / \mathrm{ha}\end{array}$ & $\begin{array}{c}\mathrm{N}_{150} \mathrm{P}_{150} \mathrm{~K}_{10} \\
0\end{array}$ & 4.05 & 6.06 & 21.06 & 19.09 & 138 \\
\hline \multicolumn{10}{|c|}{ "Mumtoz" variety } \\
\hline 7 & Control & - & - & - & 8.05 & 13.06 & 24.06 & 16.09 & 131 \\
\hline 8 & Control & - & - & $\begin{array}{c}\mathrm{N}_{150} \mathrm{P}_{150} \mathrm{~K}_{10} \\
0\end{array}$ & 8.05 & 15.06 & 01.07 & 02.09 & 147 \\
\hline 9 & "Microzym-2" & $301 / \mathrm{t}$ & - & - & 6.05 & 12.06 & 25.06 & 21.09 & 138 \\
\hline 10 & "Microzym-2" & $301 / t$ & $\begin{array}{c}40 \\
1 / \mathrm{ha}\end{array}$ & - & 6.05 & 13.06 & 29.06 & 28.09 & 145 \\
\hline 11 & $\begin{array}{c}\text { "Microzym-2" } \\
\text { +NPK }\end{array}$ & $301 / t$ & - & $\begin{array}{c}\mathrm{N}_{150} \mathrm{P}_{150} \mathrm{~K}_{10} \\
0 \\
0\end{array}$ & 6.05 & 15.06 & 02.07 & 04.09 & 151 \\
\hline 12 & $\begin{array}{l}\text { "Microzym-2" } \\
\text { +NPK }\end{array}$ & $30 \mathrm{l} / \mathrm{t}$ & $\begin{array}{c}40 \\
1 / \mathrm{ha}\end{array}$ & $\begin{array}{c}\mathrm{N}_{150} \mathrm{P}_{150} \mathrm{~K}_{10} \\
0\end{array}$ & 6.05 & 15.06 & 04.07 & 07.10 & 154 \\
\hline
\end{tabular}


It was observed that the nuts formed in the early stages from the first gynophores were large, formed seeds in 2-3 nuts, and the outer part of the nuts was thick-shelled, yellowish, and covered with network veins. In the experiment, the seeds of peanut varieties were treated with Microzym-2 biostimulator before sowing, however, in the $3 \mathrm{rd}$ and 7 th variants, where no mineral fertilizers were applied during the application period, the ripening period was 4-5 September in the "Salomat" variety experiment and for the "Mumtoz" variety, it was 18-21 September. The analysis of the duration of the ripening period in those variants showed that the average ripening period was 83-85 days for "Salomat" variety and 86-88 days for "Mumtoz" variety. The timing of the transition of peanut varieties to the ripening period was determined in phenological observations on the variants. It was observed that the influence of the studied factors on the transition periods of walnut varieties to the ripening period was significant.

The experiment showed that the application of the biostimulator Microzym-2 before sowing, during the flowering and budding phases, and the mineral fertilizers at the rate of $\mathrm{N}_{150} \mathrm{P}_{150} \mathrm{~K}_{100} \mathrm{~kg} / \mathrm{ha}$, affected the transition times of peanut varieties in options 6 and 12. In this case, the ripening period in the "Salomat" variety was on average 6-7 days later than in the control variant, that is, September 17-19, whereas in the "Mumtoz" variety, it was 9-11 days later, on October 4-7. It was identified that the growth period was higher in those variants, in which the biostimulator Microzym-2 before sowing, during the flowering and budding phases, and the mineral fertilizers at the rate of $\mathrm{N}_{150} \mathrm{P}_{150} \mathrm{~K}_{100} \mathrm{~kg} / \mathrm{ha}$ were applied. According to the data on the average 3 -year period of validity in these variants, it was noted that the growth period in the "Salomat" and "Mumtoz" variety was 12-14, and 16-18 days longer, respectively, than the control options. The effect of bio-simulators and mineral fertilizers on growth period of the peanut varieties was calculated in days, accordingly, in the variant 6, it was 138 days for "Salomat", followed by 154 days for "Mumtoz". The duration of the growth period was calculated by adding the days elapsed before the germination period towards determining the duration of the days from the date of sowing of seeds of walnut varieties to ripening. According to the 3-year experimental data on the duration of the transition to the ripening period, the average days from sowing to ripening in the variety "Salomat" was 141-147 days, and in the variety "Mumtoz" it was 159-164 days. In summary, the characteristics of early ripening were seen in the "Salomat" variety than in the "Mumtoz" variety. Due to the use of biostimulator "Microzym-2" and mineral fertilizers, the transition to the ripening period in both varieties was 12-14 days later in the "Salomat" variety and 16-18 days later in the "Mumtoz" variety. The combined use of the biostimulator Microzym-2 and mineral fertilizers had a positive effect on the normal growth of peanut varieties, the healthy appearance of the plant and the production of abundant crops.

\subsection{Effect of Microzym-2 biostimulator on change of leaf level of peanut varieties}

The period of flowering-legume formation in peanut varieties is the period of formation of the highest leaf level during the development process. In the experiment, the effect of the biostimulator and mineral fertilizers on the leaf surface of the peanut varieties, "Salomat" and "Mumtoz" was studied. In the experiment conducted in 2012, before sowing the seeds with biostimulator "Microzym-2" in the 3rd variant, the leaf area of the variety "Salomat" was 27.2 thousand $\mathrm{m}^{2} /$ ha, followed by 28.5 thousand $\mathrm{m}^{2} /$ ha in $2013,27.7$ 
thousand $\mathrm{m}^{2} / \mathrm{ha}$ in 2014 , and an average of 27.8 thousand $\mathrm{m}^{2} /$ ha in three years. In the 9 th variant of the "Mumtoz" variety treated with Microzym-2 biostimulator before sowing, the seeds were 26.3-27.4 and 26.9 thousand $\mathrm{m}^{2} /$ ha, respectively. The control was compared to the 7th variant at the expense of the biostimulator, accordingly, the leaf levels were higher by 1.6-1.9 thousand $\mathrm{m}^{2} /$ ha in the control variant (Table 5 ).

Table 4. Influence of Microzym-2 biostimulator on change of peanut leaf level.

\begin{tabular}{|c|c|c|c|c|c|c|c|c|}
\hline \multirow{3}{*}{ № } & \multirow{3}{*}{$\begin{array}{l}\text { Experimental } \\
\text { variants }\end{array}$} & \multicolumn{3}{|c|}{ Terms of use } & \multirow{3}{*}{ 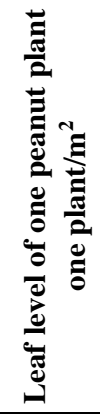 } & \multirow{2}{*}{\multicolumn{3}{|c|}{$\begin{array}{c}\text { Leaf level } \\
\text { thousand } m^{2} h a\end{array}$}} \\
\hline & & \multirow{2}{*}{ 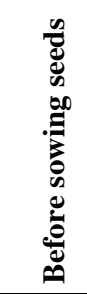 } & \multirow{2}{*}{ 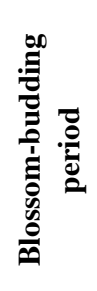 } & \multirow{2}{*}{ 苞 } & & & & \\
\hline & & & & & & 고ำ & $\stackrel{m}{\stackrel{\pi}{\pi}}$ & 胥 \\
\hline & \multicolumn{8}{|c|}{ "Salomat" variety } \\
\hline 1 & Control & - & - & - & 0.229 & 25.4 & 26.8 & 26.2 \\
\hline 2 & Control & - & - & $\mathrm{N}_{150} \mathrm{P}_{150} \mathrm{~K}_{100}$ & 0.325 & 37.8 & 39.6 & 38.5 \\
\hline 3 & "Microzym-2" & $301 / t$ & - & - & 0.226 & 27.2 & 28.5 & 27.7 \\
\hline 4 & "Microzym-2" & $301 / \mathrm{t}$ & $\begin{array}{c}40 \\
1 / \mathrm{ha}\end{array}$ & - & 0.236 & 28.3 & 29.5 & 29.1 \\
\hline 5 & $\begin{array}{l}\text { "Microzym-2" } \\
+ \text { NPK }\end{array}$ & $301 / \mathrm{t}$ & - & $\mathrm{N}_{150} \mathrm{P}_{150} \mathrm{~K}_{100}$ & 0.316 & 38.1 & 40.4 & 39.8 \\
\hline 6 & $\begin{array}{l}\text { "Microzym-2" } \\
+ \text { NPK }\end{array}$ & $301 / \mathrm{t}$ & $\begin{array}{c}40 \\
1 / \mathrm{ha}\end{array}$ & $\mathrm{N}_{150} \mathrm{P}_{150} \mathrm{~K}_{100}$ & 0.321 & 38.8 & 41.5 & 40.7 \\
\hline \multicolumn{9}{|c|}{ "Mumtoz" variety } \\
\hline 7 & Control & - & - & - & 0.214 & 24.7 & 25.5 & 25.1 \\
\hline 8 & Control & - & - & $\mathrm{N}_{150} \mathrm{P}_{150} \mathrm{~K}_{100}$ & 0.338 & 40.1 & 41.7 & 40.8 \\
\hline 9 & "Microzym-2" & $301 / \mathrm{t}$ & - & - & 0.213 & 26.3 & 27.4 & 26.9 \\
\hline 10 & "Microzym-2" & $301 / \mathrm{t}$ & $\begin{array}{c}40 \\
1 / \mathrm{ha}\end{array}$ & - & 0.220 & 26.9 & 28.2 & 27.4 \\
\hline 11 & $\begin{array}{l}\text { "Microzym-2" } \\
+ \text { NPK }\end{array}$ & $301 / \mathrm{t}$ & - & $\mathrm{N}_{150} \mathrm{P}_{150} \mathrm{~K}_{100}$ & 0.333 & 40.5 & 42.7 & 41.3 \\
\hline 12 & $\begin{array}{l}\text { "Microzym-2" } \\
+\mathrm{NPK}\end{array}$ & $301 / \mathrm{t}$ & $\begin{array}{c}40 \\
1 / \mathrm{ha}\end{array}$ & $\mathrm{N}_{150} \mathrm{P}_{150} \mathrm{~K}_{100}$ & 0.343 & 42.6 & 44.2 & 43.5 \\
\hline
\end{tabular}

In the "Salomat" variety, before sowing the seeds with the biostimulator "Microzym-2", and during flowering and budding, extra-root feeding, that was sprayed on the plant leaves in the form of a suspension in variant 4 . The plant leaf area was 28.3 thousand $\mathrm{m}^{2} / \mathrm{ha}$, in $2013-29.5$ thousand $\mathrm{m}^{2} /$ ha and 29.1 thousand $\mathrm{m}^{2} /$ ha in 2014 and an average of 29.0 thousand $\mathrm{m}^{2} /$ ha in three years. In the "Mumtoz" variety, the leaf level per hectare was 26.9, $28.2,27.4$ thousand $\mathrm{m}^{2} /$ ha in the 10 th variant and it was on average 27.5 thousand $\mathrm{m}^{2} /$ ha in three years. The leaf level per hectare was higher by 1.3-1.7 thousand $\mathrm{m}^{2}$ in the "Salomat" variety. In the experiment, the leaf level per hectare was 38.8 thousand $\mathrm{m}^{2}$ in $2012,41.5$ 
thousand $\mathrm{m}^{2}$ in 2013 and 41.5 thousand $\mathrm{m}^{2} 2014$ in the 5th variant, in which was sown with seeds of "Salomat" variety with biostimulator "Microzym-2" and mineral fertilizers were applied at the rate of $\mathrm{N}_{150} \mathrm{P}_{150} \mathrm{~K}_{100} \mathrm{~kg} / \mathrm{ha}$. It was noted that in $2014,40.7$ thousand $\mathrm{m}^{2}$ and in the "Mumtoz" variety, the average leaf area was $1.5-2.4$ thousand $\mathrm{m}^{2} /$ ha higher.

It was observed that the biostimulator Microzym-2 was more effective when used in combination with mineral fertilizers than when used in its pure form. In "Salomat" variety, the leaf level was 38.8, 41.5 and 40.7 thousand $\mathrm{m}^{2}$ in the experiment period, and the average for the period was 40.3 thousand $\mathrm{m}^{2}$ in the variant 6 and 12 , in which the biostimulator Microzym-2 before sowing, during flowering and budding and feeding with mineral fertilizers at the rate of $\mathrm{N}_{150} \mathrm{P}_{150} \mathrm{~K}_{100} \mathrm{~kg} / \mathrm{ha}$ were applied. Due to the biostimulator "Microzym-2" and mineral fertilizers, it was observed that in the 6th variant, compared to the 1 st control variant, the leaf level was $13.4,14.7$ and 14.5 thousand $\mathrm{m}^{2} /$ ha in those years and on average 14.2 thousand $\mathrm{m}^{2} /$ ha in three years. When comparing variant 6 with variant 2 , in which mineral fertilizer $\mathrm{N}_{150} \mathrm{P}_{150} \mathrm{~K}_{100} \mathrm{~kg} /$ ha was used, it was that the differences in plant leaf level was reduced. In particular, in variant 2, the leaf level was 37.8-39.6-38.5 per year and on average 38.6 thousand $\mathrm{m}^{2} /$ ha in three years, while in variant 6 , due to the use of biostimulator "Microzym-2" an additional 1.0 -1.9-2.2 and an average leaf level of 1.7 thousand $\mathrm{m}^{2} /$ ha was recorded in three years.

In summary, when comparing varieties, it was identified that the demand for nutrients in the "Mumtoz" was high, and in the 12th variant the highest leaf level is formed, and in the years of experimentation with the navigation "Salomat" was an average of 2.7-3.8 thousand $\mathrm{m}^{2} /$ ha.

\subsection{Effect of Microzym-2 biostimulator on peanut yield and oil content}

The number of ripe and unripe nuts per peanut plant was determined in the experiment. In "Salomat" and "Mumtoz" varieties, the number of legumes formed in control options 1 and 7 was the lowest, the number of legumes per peanut plant in these varieties was 17 and 20, of which 12 and 13 were ripe and 5 and 6 were not ripe, and the number of nuts harvested was 68.6 and 67.8, respectively. The results of the experiment showed that mineral fertilizers were applied at the rate of $\mathrm{N}_{150} \mathrm{P}_{150} \mathrm{~K}_{100} \mathrm{~kg} / \mathrm{ha}$. in variant 3-4, which a single plant produced an average of 31 nuts of "Salomat" variety, of which 23 (74.9\%) were ripened and $8(25.1 \%)$ were not ripe. Compared to the control variant, the use of mineral fertilizers had a higher effect on the yield of peanuts in those variants. In particular, the mineral fertilizers at the rate of $\mathrm{N}_{150} \mathrm{P}_{150} \mathrm{~K}_{100} \mathrm{~kg} / \mathrm{ha}$ in variants 3-4 that increased the yield in "Solamat" and "Mumtoz" by on average of 14 and 16 nuts per peanut plants than the control ones. The highest biometric values were recorded in variants $6-12$, where the biostimulator Microzym-2 was used before sowing, in the flowering and budding phases, as well as with mineral fertilizers $\mathrm{N}_{150} \mathrm{P}_{150} \mathrm{~K}_{100} \mathrm{~kg} / \mathrm{ha}$. In comparison "Salomat" and "Mumtoz" varieties with the variant 1 and 7, the average number of ripe and unripe nuts per plant was 15 and 18 peanuts per the plant, of which 14 and 17 peanuts were ripened, whereas 2 and 3 peanuts were unripe, accounted for $12.6 \%$ and $11.8 \%$ higher, respectively. The data obtained on the productivity of one plant depicted that it was 10.2 and 9.56 grams in the control variants 1, 7 and in the "Salomat" as well as "Mumtoz" varieties (Table 6).

In the field experiments, the biostimulator Microzym-2 was applied to the nut varieties before sowing, during the flowering and budding periods. gram high productivity was noted. The results showed that the biostimulator "Microzym-2" was applied to the nut 
varieties before sowing, during the flowering and budding periods, accordingly, in variants 4 and 10, the productivity of one plant was $1.49 \mathrm{~g}$ higher in the "Salomat" variety and 1.68 grams higher in the "Mumtoz" variety compared to the control options due to the biostimulator. Compared to Microzym-2, mineral fertilizers showed a significant effect on plant productivity. For example, when the mineral fertilizers at rate of $\mathrm{N}_{150} \mathrm{P}_{150} \mathrm{~K}_{100} \mathrm{~kg} / \mathrm{ha}$ was applied, the number of mature nuts per plant was 11 in option 6 compared to control 1 , the total number of nuts produced was 15 , and the number of ripe nuts was $6.3 \%$ higher. Although these nut varieties studied in the experiment were described as high-yielding varieties in terms of biological properties, a sharp decrease in yield elements and eventual yield was observed when they were not fed with mineral fertilizers. The highest productivity per single plant was found to be in variants 6 and 12, in which Microzym-2 biostimulator and the mineral fertilizers at the rate of $\mathrm{N}_{150} \mathrm{P}_{150} \mathrm{~K}_{100} \mathrm{~kg} / \mathrm{ha}$ were used. In those variants, the productivity was higher by 13.1 and 16.67 grams in the "Salomat" and "Mumtoz", correspondingly, than the variants 1 and 7. Due to Microzym-2 biostimulator used during the blossom-budding period, the productivity in the variants 4 and 10, especially, in the "Salomat" and "Mumtoz" ones, was higher by $3.2-3.4 \%$ than the control variants (Table 6).

Microzym-2 biostimulator was found to be more effective in 5-6-11-12 variants when used in combination with mineral fertilizers than itself in 3-4-9-10 variants. In particular, the amount of kernel from the peanut was higher by $7.7 \%$ in the "Salomat" (variant 6 ) than the control variant 1 , whereas it was $9.7 \%$ higher in the "Mumtoz" variant 12 than the control variant 7 . The experiments depicted that due to the biostimulator Microzym-2, there was a high positive correlation $(r=0.675)$ between the yield of legumes and the amount of oil in the seeds (Table 6).

Table 5. Effect of Microzym-2 biostimulator on yield elements of the peanut varieties during 20142016.

\begin{tabular}{|c|c|c|c|c|c|c|c|c|}
\hline \multirow{2}{*}{ № } & \multicolumn{3}{|c|}{$\begin{array}{c}\text { Number of nuts per } \\
\text { plant, pes }\end{array}$} & \multirow{2}{*}{$\begin{array}{c}\text { Number } \\
\text { of ripe } \\
\text { nuts, \% }\end{array}$} & \multirow{2}{*}{$\begin{array}{c}\text { Productivity of } \\
\text { one peanut } \\
\text { plant, gr }\end{array}$} & \multirow{2}{*}{$\begin{array}{l}\text { Weight of } \\
\text { nuts per } \\
\text { one plant }\end{array}$} & \multirow{2}{*}{$\begin{array}{c}\text { Kernel } \\
\text { from } \\
\text { nuts, \% }\end{array}$} & \multirow{2}{*}{$\begin{array}{c}\text { Weight } \\
\text { of } 1000 \\
\text { seeds, } \\
\text { gr }\end{array}$} \\
\hline & Ripe & Unripe & Total & & & & & \\
\hline \multicolumn{9}{|c|}{ "Salomat" variety } \\
\hline 1 & 12 & 5 & 17 & 68.67 & \begin{tabular}{|l|}
10.20 \\
\end{tabular} & 6.75 & 66.2 & 510.1 \\
\hline 2 & 23 & 8 & 31 & 74.98 & 21.56 & 15.59 & 72.3 & 536.3 \\
\hline 3 & 16 & 7 & 23 & 70.61 & 10.63 & 7.21 & 67.8 & 516.1 \\
\hline 4 & 19 & 6 & 25 & 75.02 & 11.69 & 8.11 & 69.4 & 518.5 \\
\hline 5 & 24 & 7 & 31 & 77.62 & 21.50 & 15.67 & 72.9 & 538.1 \\
\hline 6 & 26 & 6 & 32 & 81.24 & 23.30 & 17.22 & 73.9 & 539.8 \\
\hline \multicolumn{9}{|c|}{ "Mumtoz" variety } \\
\hline 7 & 13 & 6 & 20 & 67.84 & 9.56 & 6.39 & 66.8 & 673.8 \\
\hline 8 & 27 & 9 & 36 & 74.74 & 24.32 & 18.10 & 74.4 & 702.2 \\
\hline 9 & 18 & 8 & 26 & 70.14 & 9.81 & 6.77 & 69.1 & 679.5 \\
\hline 10 & 24 & 8 & 32 & 74.21 & 11.24 & 7.88 & 70.1 & 681.6 \\
\hline 11 & 28 & 8 & 36 & 78.04 & 24.39 & 18.31 & 75.1 & 703.6 \\
\hline 12 & 30 & 8 & 38 & 79.65 & 26.23 & 20.07 & 76.5 & 705.4 \\
\hline
\end{tabular}


The effect of Microzym-2 biostimulator and fertilizer standards on productivity was observed in the experiment. In "Salomat" and "Mumtoz" varieties, the lowest legume yields were observed in the control variants, accounted for $11.7 \mathrm{q} / \mathrm{ha}$ and $11.2 \mathrm{q} / \mathrm{ha}$, respectively. The analysis of the results showed that due to the use of Microzym-2 before sowing the seed, the yield of legume in the "Salomat" and "Mumtoz" were higher by on average $1.4 \mathrm{q} / \mathrm{ha}$ and $1.1 \mathrm{q} / \mathrm{ha}$ in variant 3 and 9 than the control variants 1 and $7 . \mathrm{In}$ comparison, significant differences were observed in the legume yield in variants 2 and 8 than the control variants 1 and 7 when mineral fertilizers were used instead of the growthregulating biostimulator Microzym-2. For example, the variant 2, in which mineral fertilizers were used in the "Salomat" variety, reached higher yield of $13.5 \mathrm{q} / \mathrm{ha}, 14.4 \mathrm{q} / \mathrm{ha}$ and $10.1 \mathrm{q} / \mathrm{ha}$ for 2014-2016 years, respectively than the control variant 1 . It was observed that the yield of legumes in the "Mumtoz" variety was lower than in the "Salomat" variety in the 7th variant. It can be seen that the "Mumtoz" has high requirements for water, nutrients and soil fertility. For example, in the variant 8 , when the annual rate of mineral fertilizers was $\mathrm{N}_{150} \mathrm{P}_{150} \mathrm{~K}_{100} \mathrm{~kg} / \mathrm{ha}$, it was noted that the yield potential of "Mumtoz" sharply increased. These observations depicted that significant differences in legume yields were depended on the biological characteristics of the varieties as well as the influence of external factors. In particular, in the 8th variant, the yield of legumes of the "Mumtoz" variety was $28.4 \mathrm{q} / \mathrm{ha}, 30.5 \mathrm{q} / \mathrm{ha}$ and $29.3 \mathrm{q} /$ ha over the experiment years. However, due to mineral fertilizers, the yield was $17.8 \mathrm{q} / \mathrm{ha}, 18.7 \mathrm{q} /$ ha and $18.1 \mathrm{q} /$ ha higher for 2014-2016 in the 8 th variant than in the 7 th control. It was observed that the use of the biostimulator Microzym-2 before sowing, during flowering and budding had positive effect on the growth and development of peanut varieties. Differences in the external morphological characteristics of the plants were also significant compared to the control variant. In the 6th variant of the experiment, the yield of the "Salomat" variety was on average 27.9-30.9 $\mathrm{q} / \mathrm{ha}$ during the period. The highest legume yield was observed in "Mumtoz" in $12^{\text {th }}$ variant, which were $31.8 \mathrm{q} / \mathrm{ha}, 34.8 \mathrm{q} / \mathrm{ha}$ and $33.1 \mathrm{q} /$ ha for 2014-2016, respectively. Furthermore, the average yield of "Mumtoz" variety was higher by 3.9 q/ha than the yield of "Salomat", $29.3 \mathrm{q} / \mathrm{ha}$. The see oil content of the "Salomat" was $46.9 \%$ in the control variant 1 , whereas it was higher by $0.9 \%$ in the $4^{\text {th }}$ variant due to Microzym-2, followed by $3.3 \%$ higher seed oil content in the variant 6 , in which mineral fertilizers $\mathrm{N}_{150} \mathrm{P}_{150} \mathrm{~K}_{100} \mathrm{~kg} / \mathrm{ha}$ were used. Due to the biological properties of the "Mumtoz" variety, the amount of oil in the seeds was slightly lower than the "Salomat" variety. In the control variant 2, the oil content in the seeds was $45.1 \%$. It was identified that the use of biostimulator "Microzym-2" in combination with mineral fertilizers was more effective than in pure form, and accordingly, the amount of oil in the seeds of this variety was the highest in options 11 and 12 , accounted for $47.6 \%$ and $48.4 \%$, respectively (Table 7 ).

Table 6. Effect of Microzym-2 biostimulator on nut yield and oil content (2014-2016)

\begin{tabular}{|c|c|c|c|c|c|c|c|}
\hline \multirow{2}{*}{ № } & \multicolumn{5}{|c|}{ Years } & Average & \multicolumn{2}{|c|}{ Extra nutrients } & Seed oil \\
& $\mathbf{2 0 1 4}$ & $\mathbf{2 0 1 5}$ & $\mathbf{2 0 1 6}$ & $\begin{array}{c}\text { of three } \\
\text { years }\end{array}$ & Fertilizers & $\begin{array}{c}\text { Biostimulato } \\
\text { content, } \\
\mathbf{\%}\end{array}$ \\
\hline 1 & 11.2 & 12,3 & 11.5 & 11.7 & - & - & 46.9 \\
\hline 2 & 24.7 & 26.7 & 25.6 & 25.7 & 14.0 & - & 49.1 \\
\hline
\end{tabular}




\begin{tabular}{|c|c|c|c|c|c|c|c|}
\hline 3 & 12.4 & 13.9 & 12.9 & 13.1 & - & 1.4 & 47.4 \\
\hline 4 & 13.5 & 15.4 & 14.2 & 14.4 & - & 2.7 & 47.8 \\
\hline 5 & 25.8 & 28.1 & 26.6 & 26.8 & 13.8 & 1.4 & 49.5 \\
\hline 6 & 27.9 & 30.9 & 29.1 & 29.3 & 14.9 & 2.7 & 50.2 \\
\hline \multicolumn{8}{|c|}{ "Mumtoz" variety } \\
\hline 7 & 10.6 & 11.8 & 11.2 & 11.2 & - & - & 45.1 \\
\hline 8 & 28.4 & 30.5 & 29.3 & 29.4 & 18.2 & - & 46.8 \\
\hline 9 & 11.6 & 13.1 & 12.3 & 12.3 & - & 1.1 & 45.8 \\
\hline 10 & 13.0 & 15.1 & 14.0 & 14.0 & - & 2.8 & 46.1 \\
\hline 11 & 29.4 & 31.7 & 30.2 & 30.4 & 18.1 & 1.1 & 47.6 \\
\hline 12 & 31.8 & 34.8 & 33.1 & 33.2 & 19.2 & 2.8 & 48.4 \\
\hline $\begin{array}{l}201 \\
201\end{array}$ & $\begin{array}{l}\text { ear HC } \\
\text { ear HC } \\
16 y e a r\end{array}$ & $\begin{array}{l}0.46 \mathrm{q} / \\
.39 \mathrm{q} / \\
05=0.5\end{array}$ & $\begin{array}{l}\mathrm{HCP}_{05}= \\
\mathrm{HCP}_{05}= \\
\text { a } \mathrm{HC}\end{array}$ & $\begin{array}{l}0 \\
0 \\
.72 \%\end{array}$ & & & \\
\hline
\end{tabular}

\subsection{Analysis of cost-effectiveness indicators on the effect of the biostimulator "Microzym-2"}

The experiment analyzed the cost-effectiveness of using the biostimulator "Microzym2 " in the conditions of typical gray soils of Tashkent province before sowing, flowering and legume phases. The biostimulator Microzym-2 was taken from the Microbiological Research Institute. It was stated that Microzym-2 and mineral fertilizers as extra rootfeeding during growing season were used and effective to extract higher and quality yield from "Salomat" and "Mumtoz". The amount of gross income was calculated multiplying the yield of peanut varieties by the price of one $\mathrm{kg}$ of raw material. The gross income in the 1 st variant of "Salomat" variety was 7,865.0 thousand sums, and in the 7th variant of "Mumtoz" variety, it was 6,720.0 thousand sums. However, due to the average cost 7,385.0 thousand sums, the level of profitability was the lowest in the varieties, especially $6.4 \%$ in the variety "Salomat" and $10.4 \%$ in the variety "Mumtoz". The analyzes of the costeffectiveness of the use of biostimulator showed that the gross income from the sale of the product per hectare was much by 1,925 thousand sums in 4th variant of "Salomat" than the variant 1, and it was much higher by 2,075.0 thousand sums in the variant 7th of "Mumtoz" than the variant 10.The net income from the sale of the yield of one hectare land was $7,100.7$ thousand sums in the 6th variant of the "Salomat" variety, and it was 9,236.8 thousand sums in the 12th variant of the "Mumtoz" variety (Table 8). 
Table 7. Analysis of cost-effectiveness indicators on the effect of the biostimulator "Microzym-2"

\begin{tabular}{|c|c|c|c|c|c|c|c|c|}
\hline № & $\begin{array}{l}\text { Experimental } \\
\text { variants }\end{array}$ & 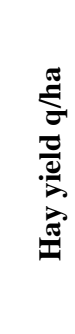 & 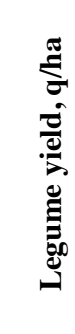 & 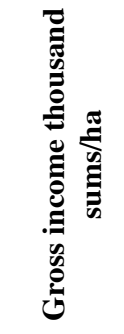 & 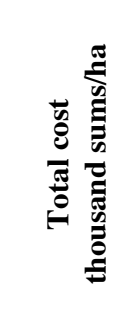 & 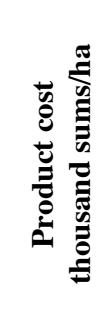 & 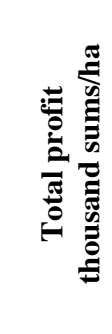 & 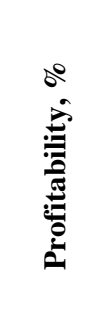 \\
\hline \multicolumn{9}{|c|}{ "Salomat" variety } \\
\hline 1 & Control & 17.3 & 11.7 & $7,865.0$ & $8,402.3$ & 7,181 & -537.3 & -6.4 \\
\hline 2 & $\begin{array}{c}\text { Control } \\
\left(\mathbf{N}_{150} \mathbf{P}_{150} K_{100}\right)\end{array}$ & 37.8 & 25.7 & $17,240.0$ & $12,300.7$ & 4,786 & $4,939.3$ & 40.2 \\
\hline 3 & $\begin{array}{r}\text { Microzym-2 } \\
(\text { seed-30 l/t) }\end{array}$ & 19.4 & 13.1 & $8,805.0$ & $8,577.3$ & 6,548 & 227.7 & 2.7 \\
\hline 4 & $\begin{array}{c}\text { Microzym-2 } \\
\text { (seed-30 1/t+ } \\
\text { blossom-40 1/ha) }\end{array}$ & 22.1 & 14.4 & $9,790.0$ & $9,003.2$ & 6,252 & 786.8 & 8.7 \\
\hline 5 & $\begin{array}{c}\text { Microzym-2 } \\
(\text { seed-30 l/t) + } \\
\text { N}_{150} \mathbf{P}_{150} \mathbf{K}_{100}\end{array}$ & 38.2 & 26.8 & $17,790.0$ & $12,339.9$ & 4,604 & $5,450.1$ & 44.2 \\
\hline 6 & $\begin{array}{c}\text { Microzym-2 } \\
\text { (seed-30 I/t+ } \\
\text { blossom }(40 \mathrm{l} / \mathrm{ha}) \\
+\mathrm{N}_{150} \mathrm{P}_{150} \mathrm{~K}_{100} \\
\end{array}$ & 42.1 & 29.3 & $20,525.0$ & $13,424.3$ & 4,416 & $7,100.7$ & 52.9 \\
\hline \multicolumn{9}{|c|}{ "Mumtoz" variety } \\
\hline 7 & Control & 15.6 & 11.2 & $7,385.0$ & $8,242.1$ & 7,359 & -857.1 & -10.4 \\
\hline 8 & $\begin{array}{c}\text { Control } \\
\left(\mathrm{N}_{150} \mathrm{P}_{150} \mathrm{~K}_{100}\right)\end{array}$ & 42.5 & 29.4 & $19,600.0$ & $12,466.1$ & 4,240 & 7133.9 & 57.2 \\
\hline 9 & $\begin{array}{l}\text { Microzym-2 } \\
(\text { seed-30 l/t) }\end{array}$ & 18.3 & 12.3 & $8,285.0$ & $8,588.5$ & 6,983 & -303.5 & -3.5 \\
\hline 10 & $\begin{array}{c}\text { Microzym-2 } \\
\text { (seed-30 1/t+ } \\
\text { blossom-40 1/ha) }\end{array}$ & 21.1 & 14 & $9,460.0$ & $8,947.9$ & 6,391 & 512.1 & 5.7 \\
\hline 11 & $\begin{array}{c}\text { Microzym-2 } \\
(\text { seed-30 l/t) }+ \\
\mathbf{N}_{150} \mathbf{P}_{150} \mathbf{K}_{100}\end{array}$ & 45.6 & 30.4 & $20,525.0$ & $12,615.1$ & 4,150 & $7,909.9$ & 62.7 \\
\hline 12 & $\begin{array}{c}\text { Microzym-2 } \\
\text { (seed-30 I/t+ } \\
\text { blossom }(40 \mathrm{l} / \mathrm{ha}) \\
+\mathrm{N}_{150} \mathrm{P}_{150} \mathrm{~K}_{100} \\
\end{array}$ & 49.4 & 33.2 & $22,355.0$ & $13,118.2$ & 3,951 & $9,236.8$ & 70.4 \\
\hline
\end{tabular}

\section{Conclusions}


Microzym-2 biostimulator at the rate of $30 \mathrm{l} / \mathrm{t}$ before sowing, at the rate of $40 \mathrm{l} / \mathrm{ha}$ during flowering-budding and mineral fertilizers at rate of $\mathrm{N}_{150} \mathrm{P}_{150} \mathrm{~K}_{100} \mathrm{~kg} / \mathrm{ha}$ were applied in "Mumtoz" and "Salomat" peanut varieties, consequently, 27.9 q/ha and 34.8 q/ha peanut were harvested from those varieties. The highest legume yield was observed in "Mumtoz" in $12^{\text {th }}$ variant, which were $31.8 \mathrm{q} / \mathrm{ha}, 34.8 \mathrm{q} /$ ha and $33.1 \mathrm{q} /$ ha for 2014-2016, respectively. Furthermore, the average yield of "Mumtoz" variety was higher by 3.9 q/ha than the yield of "Salomat", $29.3 \mathrm{q} / \mathrm{ha}$.

The see oil content of the "Salomat" was $46.9 \%$ in the control variant 1 , whereas it was higher by $0.9 \%$ in the $4^{\text {th }}$ variant due to Microzym-2, followed by $3.3 \%$ higher seed oil content in the variant 6 , in which mineral fertilizers $\mathrm{N}_{150} \mathrm{P}_{150} \mathrm{~K}_{100} \mathrm{~kg} / \mathrm{ha}$ were used. Due to the biological properties of the "Mumtoz" variety, the amount of oil in the seeds was slightly lower than the "Salomat" variety. In the control variant 2, the oil content in the seeds was $45.1 \%$. It was identified that the use of biostimulator "Microzym-2" in combination with mineral fertilizers was more effective than in pure form, and accordingly, the amount of oil in the seeds of this variety was the highest in options 11 and 12, accounted for $47.6 \%$ and $48.4 \%$, respectively.

It was found that the gross income in the 1 st variant of "Salomat" variety was 7865.0 thousand sums, and in the 7th variant of "Mumtoz" variety, it was 6720.0 thousand sums. However, due to the average cost 7385.0 thousand sums, the level of profitability was the lowest in the varieties, especially $6.4 \%$ in the variety "Salomat" and $10.4 \%$ in the variety "Mumtoz". The analyzes of the cost-effectiveness of the use of biostimulator showed that the gross income from the sale of the product per hectare was much by 1925 thousand sums in 4th variant of "Salomat" than the variant 1, and it was much higher by 2075.0 thousand sums in the variant 7th of "Mumtoz" than the variant 10 .

\section{References}

1. I. H. Al-Hilfy, S.A. Al-Salmani, Advances in Environmental Biology 13(5), 7-13 (2019)

2. M. Mondal, M. Skalicky, S. Garai, A. Hossain, S. Sarkar, H. Banerjee, A. M. Laing, Agronomy 10(10), 1513. (2020)

3. S. Isaev, I. Begmatov, G. Goziev, S. Khasanov, IOP Publishing 883(1), 012080 (2020)

4. S. K. Isaev, R. U. Rakhmonov, S. S. Tadjiev, G. I. Goziev, S. Z. Khasanov, IOP Publishing 614(1), 012147 (2020)

5. KH. N. Atabayeva J. B. Khudaykulov, M. E. Amanova, Methods of designing field experiments, 146 (TSAU press, Tashkent, 2019)

6. J. B. Khudaykulov, F. Babajanova, Bulletin of Khorezm Mamun Academy 5(06), 2123 (2016)

7. J. B. Khudaykulov, AGRO ILM 2(46), 35-36 (2017)

8. A. Jumanov, S. Khasanov, A. Tabayev, G. Goziev, U. Uzbekov, E. Malikov, IOP Publishing 614(1), 012150 (2020)

9. J. B. Khudaykulov, AGRO ILM 9(10), 149-152 (2018)

10. J. B. Khudaykulov, Agrochemical protection and plant quarantine 2(11), 42-45 (2017)

11. J. Khudaykulov, European Applied Science 5(06), 3-6 (2017)

12. X. N. Atabaeva, J. B. Xudayqulov, Collection of materials of the Republican scientific-practical conference, 358-361 (2019) 
13. J. B. Khudaykulov, F. Mukhtarov, Collection of materials of the Republican scientificpractical conference, 361-364 (2019)

14. S. R. Nigam, R. C. Rao, J. C.Wynne, J. Argon. Crop. Sci. 181, 117-124 (1998) 